\title{
PENGARUH JENIS PACKING PADA MENARA PACKED-BED ABSORBER DALAM PENYERAPAN GAS NOx
}

\author{
Agoeng Kadarjono, Erilia Yusnitha, Agus Sartono Dwi Santosa, Pertiwi Diah Winastri \\ Pusat Teknologi Bahan Bakar Nuklir - BATAN \\ Kawasan PUSPIPTEK Serpong Gd.20 Tangerang Selatan, Banten 15314 \\ e-mail: agoenk@batan.go.id \\ (Naskah diterima: 19-12-2019, Naskah direvisi: 30-01-2020, Naskah disetujui: 25-02-2020)
}

\begin{abstract}
ABSTRAK
PENGARUH JENIS PACKING PADA MENARA PACKED-BED ABSORBER DALAM PENYERAPAN GAS NOx. Desain proses efluen gas NOx perlu dilakukan dalam aktifitas pembuatan broth dan casting pada rangkaian proses fabrikasi kernel $\mathrm{UO}_{2}$. Dengan tersedianya alat proses efluen, maka akan meningkatkan nilai ekonomis, efisiensi proses, mengurangi kebutuhan bahan kimia, meminimalisir bahaya toksisitas dan kontaminasi. Desain alat proses efluen dipilih menara packed-bed absorber menggunakan aliran umpan gas NOx dan air sebagai media penyerap. Menara packed-bed absorber didesain dan dihitung untuk mengetahui pengaruh berbagai jenis packing (pall, ralu, dan nor-pac ring) dalam penyerapan gas NOx. Untuk menentukan pengaruh jenis packing tersebut, dilakukan dengan cara simulasi laju alir fluida terhadap diameter, luas permukaan efektif packing, pressure drop, koefisien perpindahan massa, tinggi kolom packing, dan tinggi menara dengan cara memasukkan ke dalam persamaan-persamaan yang sesuai menggunakan program EXCEL. Hasil perhitungan menunjukkan bahwa pengaruh laju alir gas tidak terlalu signifikan terhadap diameter menara, sedangkan laju alir air menghasilkan diameter menara bertambah besar. Luas permukaan efektif packing cenderung menurun pada kenaikan laju alir fluida. Pressure drop, koefisien perpindahan massa, tinggi kolom packing, dan tinggi menara bertambah besar pada kenaikan laju alir gas, dan cenderung menurun bila laju alir air dinaikkan. Kenaikan penyerapan gas NOx menyebabkan kenaikan tinggi menara, sedangkan kenaikan faktor flooding menyebabkan penurunan tinggi kolom packing dan tinggi menara. Kenaikan tekanan dan temperatur operasi menyebabkan penurunan tinggi kolom packing dan tinggi menara. Packing jenis pall ring menjadi pilihan desain karena menghasilkan dimensi yang kecil atau ekonomis.
\end{abstract}

Kata kunci: HTGR, kernel, efluen gas, absorber, packed-bed, packing, desain. 


\begin{abstract}
THE EFFECT OF PACKING TYPE ON THE PACKED-BED ABSORBER IN ABSORPTION OF

NOx. Design of NOx effluent gas processing needs to be done for broth preparation and gel casting activities in the UO2 kernel fabrication process series. The availability of this effluent processing tool will increase the economic value and process efficiency, reduce the amount of the chemicals needed, and minimize the hazards associated with toxicity and contamination. The design of the effluent processing tool chose the packed-bed absorber using NOx gas as a feed stream and water as an absorbent medium. The packed-bed absorber has been designed and calculated to determine the effect of various types of packing (pall, ralu, and nor-pac ring) for the absorbtion of the NOx gas. To determine the effect of the packing type, it is carried out by simulating fluid flow rate on diameter, effective surface area of packing, pressure drop, mass transfer coefficient, packing column height, and tower height by inserting into the appropriate equations using the EXCEL program. The inclusion of the effect of feed flow rate and type of packing in the calculation resulted in smaller diameter for the tower containing pall ring packing than the diameter of tower containing other fillings but gave higher pressure drop values, effective surface area of packing, total mass transfer coefficient, and tower height. Increase in NOx gas absorption causes an increase in the amount of packing space and tower height. Increase in operating pressure and temperature causes a decrease in packing and tower height, whereas increase in flooding factor, beside causing a decrease in packing and tower height, decreases the tower diameter. This type of pall ring packing is a design choice because it produces small/economic dimensions
\end{abstract}

Keywords: HTGR, kernel, gas effluent, absorber, packed-bed, packing, design 


\section{PENDAHULUAN}

Penelitian dan pengembangan reaktor maju berjenis HTGR (High Temperature Gas Cooled Reactor) sedang dilakukan oleh BATAN. Reaktor ini menggunakan bahan bakar jenis partikel berlapis (BISO/TRISO) yaitu sekumpulan kernel $\mathrm{UO}_{2}$ yang terdispersi dalam matriks grafit dan dilapisi dengan shell grafit dengan ketebalan tertentu menjadi bahan bakar berbentuk bola[1]. Kernel merupakan jenis bahan bakar yang dalam fabrikasinya melibatkan beberapa proses seperti: pembuatan broth, pembentukan kernel, ageing, washing, drying, kalsinasi, reduksi, dan sintering. Pembuatan broth dilakukan dengan cara melarutkan material uranium (yellow cake atau uranium oksida) menggunakan pelarut asam nitrat[2,3].

Peralatan proses fabrikasi kernel telah dimiliki PTBBN - BATAN dalam skala laboratorium namun belum dilengkapi dengan alat proses efluen, sehingga desain proses efluen gas NOx perlu dilakukan untuk meningkatkan nilai ekonomi, efisiensi proses, mengurangi kebutuhan bahan kimia, mencegah pencemaran lingkungan akibat toksisitas kimia, dan meminimalisir bahaya kontaminasi yang diakibatkan oleh partikel uranium dalam efluen gas[4].

Absorpsi gas NOx pada proses pembuatan broth menjadi proses yang penting mengingat gas NOx berbahaya bagi pekerja maupun lingkungan, terutama jika terkontaminasi uranium. Berbagai macam alat dapat mengabsorpsi gas NOx diantaranya absorber[5]. Absorber digunakan untuk sebagian besar industri dan pabrik untuk memisahkan gas, memulihkan produk dan bahan kimia yang berharga, serta untuk pengendalian kontaminasi. Jenis absorber yang paling umum digunakan dalam industri adalah plate column, packed tower, menara venturi dan spray chamber. Menara packed biasa digunakan pada proses pemisahan seperti distilasi, ekstraksi, adsorpsi, dan kromatografi[ $6,7,8,9]$.
Desain menara packed dimulai dari pemilihan tipe dan ukuran packing, penentuan diameter menara untuk menangani laju alir gas dan cairan, penentuan tinggi menara, pemilihan dan desain fitur internal menara[10]. Tipe-tipe packing yang digunakan sebagai isian menara harus menyediakan luas permukaan yang besar untuk kontak antara cairan dan gas, tahan aliran gas, menawarkan distribusi cairan yang seragam pada permukaan packing, dan menawarkan aliran gas yang menyebar di sepanjang ruang menara[11].

\section{Penentuan Diameter Menara Packed-bed Absorber}

Dalam menentukan diameter menara packed-bed absorber $(\mathrm{D}, \mathrm{m})$, parameter yang harus dihitung adalah berat molekul gas $\left(M_{\mathrm{G}}\right.$, $\mathrm{kg} / \mathrm{kmol})$, laju alir gas $\left(Q_{\mathrm{G}}, \mathrm{m}^{3} / \mathrm{j}\right)$, jumlah gas Nox yang diabsorpsi $\left(m_{\mathrm{NO}}, \mathrm{kg} / \mathrm{j}\right)$, jumlah cairan yang keluar menara $\left(m_{\llcorner 1}, \quad \mathrm{kg} / \mathrm{j}\right)$, parameter aliran $(X)$, pressure drop pada kondisi flooding ( $\left.Y_{\text {flood, }}, \mathrm{Pa} / \mathrm{m}\right)$, koefisien flooding ( $C_{\text {Sflood) }}$, kecepatan gas pada kondisi flooding $\left(v_{\mathrm{G}}, \mathrm{m} / \mathrm{dt}\right)$. Dengan menggunakan metode Kay dan korelasi Pavlov, diameter menara dapat ditentukan berturut-turut dengan menggunakan persamaan (1) hingga (9) yaitu:

$$
\begin{aligned}
& M_{\mathrm{G}}=\left(y_{\mathrm{NOx}} \cdot M_{\mathrm{NOx}}\right) \\
& m_{\mathrm{NOx}(\mathrm{abs})}=\left(\frac{Q_{\mathrm{G}} \cdot \rho_{\mathrm{G}}}{M_{\mathrm{G}}}\right) y_{\mathrm{NOx}} \cdot \% R \cdot M_{\mathrm{G}} \\
& m_{\mathrm{L}(1)}=m_{\mathrm{L}(2)}+m_{\mathrm{NOx}(\mathrm{abs})} \\
& X=\frac{m_{\mathrm{L}(1)}}{Q_{\mathrm{G}} \cdot \rho_{\mathrm{G}}} \cdot\left(\frac{\rho_{\mathrm{G}}}{\rho_{\mathrm{L}}}\right)^{0.5} \\
& \ln Y_{\text {flood }}=-\left[3,5021+1,028 \ln X+0,11093(\ln X)^{2}\right] \\
& C_{\text {Sflood }}=\left[\frac{Y_{\text {flood }}}{F_{\mathrm{P}} \cdot \mu_{\mathrm{L}} 0.1}\right]^{0.5} \\
& v_{\mathrm{G} f l o o d}=\frac{c_{S f l o o d}}{\left[\frac{\rho_{\mathrm{G}}}{\rho_{\mathrm{L}}-\rho_{\mathrm{G}}}\right]^{0.5}} \\
& v_{\mathrm{G}}=v_{\mathrm{Gflood}} \cdot f_{\text {flood }} \\
& D=\left[\frac{4 \cdot\left(\frac{Q_{\mathrm{G}}}{3600}\right)}{v_{\mathrm{G}} \cdot \pi}\right]^{0.5}
\end{aligned}
$$




\section{Perhitungan Luas Permukaan efektif dan Pressure drop}

Hal-hal yang perlu ditentukan sebelum menghitung besaran pressure drop antara lain penetapan batas pressure drop gas antara $200-400 \mathrm{~Pa} / \mathrm{m}$ pada kedalaman packed-bed absorber agar perancangan aman dari kondisi flooding. Untuk itu pressure drop pada kondisi gas kering $(\Delta \mathrm{Po} / \mathrm{Z}, \mathrm{Pa} / \mathrm{m}))$ dan total $(\Delta \mathrm{P} / \mathrm{Z}, \mathrm{Pa} / \mathrm{m})$ harus ditentukan dengan menggunakan persamaan yang tepat. Sebelum menentukan nilai kedua pressure drop tersebut, langkah-langkah yang harus dihitung antara lain diameter partikel efektif $(d p, \quad m)$, faktor dinding $(K w)$, bilangan Reynolds gas (ReG), koefisien ketahanan packing kering $\left(\psi_{0}\right)$, kecepatan massa cairan (GL, $\mathrm{kg} / \mathrm{m}^{2} . \mathrm{dt}$ ), kecepatan cairan ( $\mathrm{L}, \mathrm{m} / \mathrm{dt}$ ), bilangan Reynolds cairan $(R e \mathrm{~L})$, bilangan Froude cairan $(F n)$, rasio luas permukaan $\left(a_{n} / a, m^{-1}\right)$, luas permukaan spesifik efektif packing $\left(a_{n}, \mathrm{~m}^{-1}\right)$, dan waktu tinggal cairan $(h\llcorner, \mathrm{j})$.

$$
\begin{aligned}
& d_{\mathrm{P}}=6 \cdot\left(\frac{1-\varepsilon}{a}\right) \\
& K_{\mathrm{W}}=\frac{1}{1+\frac{2}{3} \cdot\left(\frac{1}{1-\varepsilon}\right) \cdot \frac{d_{\mathrm{P}}}{D}} \\
& R e_{\mathrm{G}}=\frac{v_{\mathrm{G}} \cdot d_{\mathrm{P}} \cdot \rho_{\mathrm{G}} \cdot K_{\mathrm{W}}}{(1-\varepsilon) \cdot \mu_{\mathrm{G}}} \\
& \psi_{0}=C_{\mathrm{P}} \cdot\left[\frac{64}{R e_{\mathrm{G}}}+\frac{1 \cdot 8}{R e_{\mathrm{G}} 0^{0.08}}\right] \\
& G_{\mathrm{L}}=\frac{4 \cdot\left(\frac{m_{\mathrm{L}(1)}}{\pi 600}\right)}{\pi \cdot D^{2}} \\
& v_{\mathrm{L}}=\frac{G_{\mathrm{L}}}{\rho_{\mathrm{L}}} \\
& R e_{\mathrm{L}}=\frac{v_{\mathrm{L}} \cdot \rho_{\mathrm{L}}}{a \cdot \mu_{\mathrm{L}}} \\
& F r_{\mathrm{L}}=\frac{v_{\mathrm{L}}{ }^{2} \cdot a}{g} \\
& \frac{a_{\mathrm{h}}}{a}=0,85 \cdot C_{\mathrm{h}} \cdot R e_{\mathrm{L}}{ }^{0.25} \cdot F r_{\mathrm{L}}{ }^{0.1} \text { untuk } R e_{\mathrm{L}} \geq 5 \\
& a_{\mathrm{h}}=\frac{a_{\mathrm{h}}}{a} \cdot a \\
& h_{\mathrm{L}}=\left[12 \cdot \frac{F r_{\mathrm{L}}}{R e_{\mathrm{L}}}\right]^{1 / 3} \cdot\left[\frac{a_{h}}{a}\right] \\
& \frac{\Delta \mathrm{P}_{0}}{Z}=\psi_{0} \cdot \frac{a}{\varepsilon^{3}} \cdot \frac{\rho_{\mathrm{G}} \cdot v_{\mathrm{G}}{ }^{2}}{2} \cdot \frac{1}{K_{\mathrm{W}}} \\
& \frac{\Delta P}{Z}=\frac{\Delta P_{0}}{Z} \cdot\left[\left(\frac{\varepsilon}{\varepsilon-h_{\mathrm{L}}}\right)^{1 \cdot 5} \exp \left(\frac{R e_{\mathrm{L}}}{200}\right)\right]
\end{aligned}
$$

\section{Penentuan Koefisien Perpindahan Massa}

Sebelum menentukan koefisien perpindahan massa gas $(\mathrm{kG})$ atau cairan $(\mathrm{kL})$, terlebih dahulu ditentukan nilai koefisien difusi. Koefisien difusi dalam sistem biner dalam tekanan rendah, dapat menggunakan korelasi Wilke and Lee $\left(D_{\mathrm{G}}, \mathrm{m}^{2} / \mathrm{dt}\right)$ untuk gas dan korelasi Minhas and Hayduk untuk cairan ( $\left.D \mathrm{~L}, \mathrm{~m}^{2} / \mathrm{dt}\right)$. Selanjutnya terlebih dahulu, dihitung faktor temperatur $\left(T^{*}, \mathrm{~K}\right)$, tumbukan difusi $(\Omega \mathrm{D})$, diameter tumbukan $(\sigma, \AA)$, berat molekul $(M, \mathrm{~kg} / \mathrm{kmol})$, volume molar $\left(V_{N O X}\right.$, $\mathrm{cm}^{3} / \mathrm{mol}$ ), viscositas air ( $\mu \mathrm{w}$, Pa.dt), dan faktor volume molar $(n)$. Nilai koefisien perpindahan massa dapat dicari dengan menggunakan korelasi yang dibuat oleh Billet dan Schultes, meliputi koefisien perpindahan massa konvektif gas $\left(k_{\mathrm{G}}, \mathrm{kmol} / \mathrm{m}^{2}\right.$.dt) dan cairan ( $\mathrm{L}_{\mathrm{L}}$, $\mathrm{m} / \mathrm{dt}$ ). Untuk menentukan besaran kedua koefisien tersebut, maka harus ditentukan dahulu nilai dari bilangan Schmidt ( $\left.S_{\mathrm{cG}}\right)$, faktor perpindahan massa dari jenis packing yang digunakan untuk gas $\left(C_{V}\right)$ dan untuk cairan $\left(C_{L}\right)$, nilai tetapan gas ideal $(R=$ $\left.0,0821 \mathrm{~m}^{3} . \mathrm{atm} / \mathrm{kmol} . \mathrm{K}\right)$, fraksi pori packing $(\varepsilon)$, dan luas permukaan perpindahan massa per unit volume $\left(a, \mathrm{~m}^{-1}\right)$, berturut-turut:

$$
\begin{aligned}
T^{\star}= & \frac{T}{\sqrt{\frac{e}{k}}{ }^{N o x}} \\
\Omega_{\mathrm{D}}= & \frac{1,06036}{\left(T^{*}\right)^{0,1561}}+\frac{0,19300}{\exp \left(0,47635 \cdot T^{*}\right)}+ \\
& \frac{1,03587}{\exp \left(1,52996 \cdot T^{*}\right)}+\frac{1,76474}{\exp \left(3,89411 \cdot T^{*}\right)}
\end{aligned}
$$

$D_{\mathrm{G}}=\frac{\left[3,03-\left(\frac{0,98}{M_{\mathrm{NO}} x^{1 / 2}}\right)\right] \cdot\left(10^{-3}\right) \cdot T^{3 / 2}}{P \cdot M_{\mathrm{NO}} x^{1 / 2} \cdot \sigma_{\mathrm{NO}}{ }^{2} \cdot \Omega_{\mathrm{D}}}$

$n=\frac{9,58}{V_{\mathrm{NO}}}-1,12$

$D_{\mathrm{L}}=\frac{1,25 \times 10^{-8} \cdot\left(V_{\mathrm{NOX}}{ }^{-0,19}-0,292\right) \cdot \mathrm{T}^{1,52} \cdot \mu_{\mathrm{W}}{ }^{n}}{10000}$

$S c_{\mathrm{G}}=\frac{\mu_{\mathrm{G}}}{\rho_{\mathrm{G}} \cdot D_{\mathrm{G}}}$

$k_{\mathrm{G}}=$

$0,1304 . C_{V} \cdot\left[\frac{D_{\mathrm{G}} \cdot P}{R \cdot T}\right] \cdot\left[\frac{a}{\left[\varepsilon\left(\varepsilon-h_{\mathrm{L}}\right)\right]^{0.5}}\right] \cdot\left[\frac{R e_{\mathrm{G}}}{K_{\mathrm{W}}}\right] \cdot S c_{\mathrm{G}}{ }^{2 / 3}$

$k_{\mathrm{L}}=0,757 \cdot C_{L} \cdot\left[\frac{D_{\mathrm{L}} \cdot a \cdot v_{\mathrm{L}}}{\varepsilon \cdot h_{\mathrm{L}}}\right]^{0,5}$ 


\section{Penentuan Tinggi Kolom Packing dan Tinggi Menara}

Penentuan tinggi menara $(Z)$ berturut-turut dimulai dari perhitungan laju alir molar gas ( $\left.N_{\mathrm{G}}, \mathrm{kmol} / \mathrm{j}\right)$, kecepatan molar gas masuk menara (GMy(1), $\left.\mathrm{kmol} / \mathrm{m}^{2} . \mathrm{dt}\right)$, kecepatan molar gas keluar menara ( $G_{\text {My(2), }}$, $\left.\mathrm{kmol} / \mathrm{m}^{2} . \mathrm{dt}\right)$, kecepatan molar gas rata-rata $\left(G_{M y}, \mathrm{kmol} / \mathrm{m}^{2} . \mathrm{dt}\right)$, kecepatan molar cairan masuk ( $\left.\mathrm{Gm}_{\mathrm{M} \times(1)}, \mathrm{kmol} / \mathrm{m}^{2} . \mathrm{dt}\right)$, kecepatan molar cairan keluar $\left(G_{\mathrm{Mx}(2)}, \mathrm{kmol} / \mathrm{m}^{2} . \mathrm{dt}\right)$, kecepatan molar rata-rata $\left(G_{\mathrm{Mx}}, \mathrm{kmol} / \mathrm{m}^{2} . \mathrm{dt}\right)$, faktor absorpsi daerah bawah $\left(A_{(1)}\right)$ dan atas $\left(A_{(2)}\right)$ menara, faktor absorpsi rata-rata $(A)$, koefisien perpindahan massa volumetrik gas $\left(K_{\mathrm{vG}}, \mathrm{kmol} / \mathrm{m}^{3} . \mathrm{dt}\right)$, cairan $\left(K_{\mathrm{vL}}, \mathrm{kmol} / \mathrm{m}^{3} . \mathrm{dt}\right)$, total $\left(K_{\mathrm{m}}, \mathrm{kmol} / \mathrm{m}^{3} . \mathrm{dt}\right)$, tinggi kolom packing ( $\left.H_{\mathrm{tOG}}, \mathrm{m}\right)$, jumlah kolom packing $\left(N_{\mathrm{toG}}\right)$, koefisien distribusi $(\phi)$, dan tinggi menara $(Z$, $\mathrm{m})$.

$$
\begin{aligned}
& N_{\mathrm{G}}=\left(\frac{Q_{\mathrm{G}} \cdot \rho_{\mathrm{G}}}{M_{\mathrm{G}}}\right) \\
& G_{\mathrm{My}(1)}=\frac{4 \cdot N_{\mathrm{G}}}{3600 \cdot \pi \cdot D^{2}} \\
& N_{\mathrm{NOx}(\mathrm{abs})}=\left(\frac{Q_{\mathrm{G}} \cdot \rho_{\mathrm{G}}}{M_{\mathrm{G}}}\right) \cdot y_{\mathrm{NOx}} \cdot \% R \\
& G_{\mathrm{My}(2)}=\frac{4 \cdot\left(N_{\mathrm{G}}-N_{\mathrm{NOx}(\mathrm{abs})}\right)}{3600 \cdot \pi \cdot D^{2}} \\
& G_{\mathrm{My}}=\frac{G_{\mathrm{My}(1)}+G_{\mathrm{My}(2)}}{2} \\
& N_{L(2)}=\left(\frac{m_{L(2)}}{M_{W}}\right) \\
& G_{\mathrm{Mx}(1)}=\frac{4 \cdot\left(N_{\mathrm{L}(2)}+N_{\mathrm{NOx}}(\mathrm{abs})\right.}{3600 \cdot \pi \cdot D^{2}} \\
& G_{M x(2)}=\frac{4 \cdot N_{L(2)}}{3600 \cdot \pi \cdot D^{2}} \\
& A_{(1)}=\frac{G_{M x(1)}}{G_{M y(1)} \cdot \varnothing} \\
& A_{(2)}=\frac{G_{M x(2)}}{G_{M y(2)} \cdot \varnothing} \\
& A=\frac{A_{(1)}+A_{(2)}}{2} \\
& y_{\mathrm{NOx}(2)}=(1-\% R) \cdot y_{\mathrm{NOx}(1)} \\
& K_{\mathrm{VG}}=k_{\mathrm{G}} \cdot a_{\mathrm{h}} \\
& c=\frac{\rho_{1}}{M_{\mathrm{W}}} \\
& K_{\mathrm{VL}}=k_{\mathrm{L}} \cdot a_{\mathrm{h}} \cdot c \\
& K_{\mathrm{m}}=\frac{1}{\frac{1}{K_{\mathrm{VG}}} \cdot \frac{\emptyset}{K_{\mathrm{vL}}}} \\
&
\end{aligned}
$$

$$
\begin{aligned}
& H_{\mathrm{tOG}}=\frac{G_{\mathrm{My}}}{K_{\mathrm{m}}} \\
& {\left[x_{\mathrm{NOx}(1)}\right]=\frac{N_{\mathrm{NOx}(\mathrm{abs})}}{N_{\mathrm{L}(1)}}=\frac{N_{\mathrm{NOx}(\mathrm{abs})}}{N_{\mathrm{L}(2)}+N_{\mathrm{NOx}(\mathrm{abs})}}} \\
& N_{\mathrm{tOG}}=\frac{\ln \left\{\left[\frac{y_{\mathrm{NOx}(1)}-\left(\varnothing \cdot x_{\mathrm{NOx}(2)}\right)}{y_{\mathrm{NOx}(2)}-\left(\varnothing \cdot x_{\mathrm{NOx}(2)}\right)} \cdot\left(1-\frac{1}{A}\right)\right]+\frac{1}{A}\right\}}{1-\frac{1}{A}} \\
& Z=H_{t O G} \cdot N_{t O G}
\end{aligned}
$$

Skema aliran fluida dalam menara packed-bed, jenis, dan parameter packing ditampilkan pada Gambar 1, 2, dan Tabel 1.

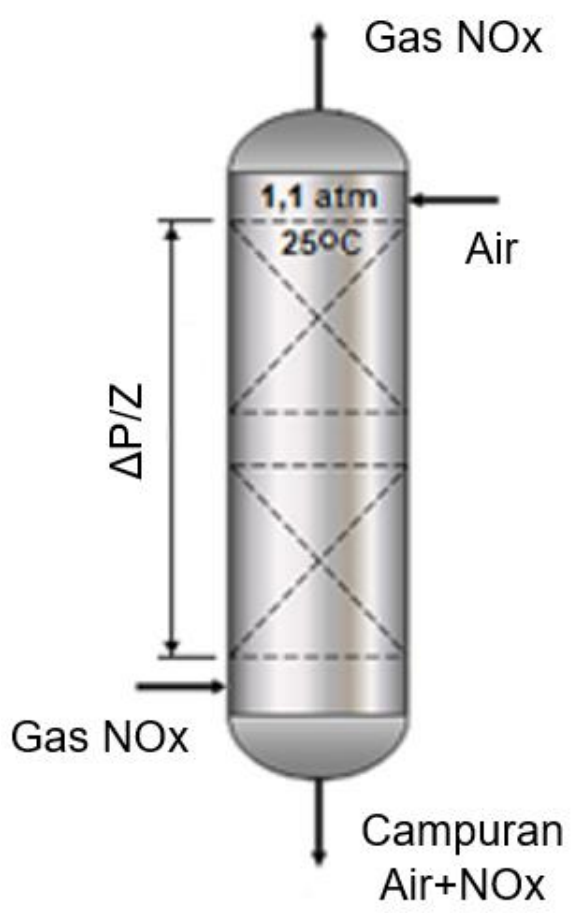

Gambar 1. Skema aliran fluida dalam menara packed-bed[6].

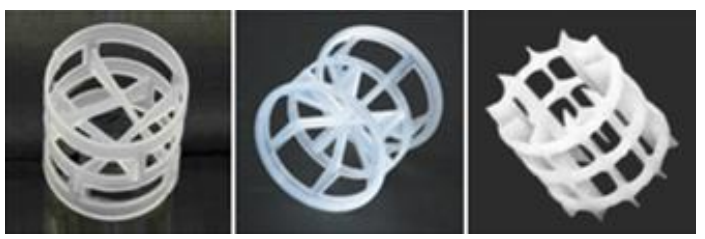

(a)

(b)

(c)

Gambar 2. Model beberapa jenis packing yang digunakan dalam perhitungan[6,12].
a) $25 \mathrm{~mm}$ pall ring plastik
b) $25 \mathrm{~mm}$ ralu ring plastik
c) $25 \mathrm{~mm}$ nor-pac ring plastik 
Tabel 1 Parameter perpindahan massa dan hidrolika beberapa jenis packing[6,13]

\begin{tabular}{|c|c|c|c|c|c|c|c|}
\hline \multirow[t]{2}{*}{ Tipe packing } & \multicolumn{5}{|c|}{ Parameter hidrolik } & \multicolumn{2}{|c|}{$\begin{array}{l}\text { Parameter } \\
\text { perpindahan } \\
\text { massa }\end{array}$} \\
\hline & $a$ & $\varepsilon$ & Ch & $C_{P}$ & $F_{P}$ & $C_{L}$ & $C_{V}$ \\
\hline 25-mm pall ring plastik & 225,0 & 0,887 & 0,528 & 0,865 & 55 & 0,905 & 0,446 \\
\hline 25-mm ralu ring plastik & 190,0 & 0,94 & 0,719 & 0,800 & 233,4 & 1,320 & 0,333 \\
\hline 25-mm nor-pac ring plastik & 202,0 & 0,953 & 0,601 & 0,397 & 402,5 & 0,883 & 0,366 \\
\hline
\end{tabular}

Sejauh sepengetahuan penulis, banyak tersedia jenis absorber dan packing, namun belum ada peneliti yang melakukan pengembangan desain alat proses untuk efluen dari proses fabrikasi kernel[14]. Pada penelitian ini mencoba membahas pengaruh jenis packing pada menara absorber pada skala laboratorium dan memilih jenis packing yang sesuai, melalui tahapan perhitungan desain menara absorber menggunakan program EXCEL

\section{METODOLOGI}

Desain menara packed-bed dimulai dari penentuan jenis packing, ukuran packing, posisi gas dan air sebagai aliran masuk dan keluar sesuai dengan Gambar 1 . Aliran gas NOx dihasilkan dari proses pelarutan serbuk $\mathrm{U}_{3} \mathrm{O}_{8}$ menggunakan larutan asam nitrat, sedangkan aliran air dari air bebas mineral (ABM). Untuk menentukan pengaruh jenis packing (pall ring, ralu ring,

$$
\mathrm{U}_{3} \mathrm{O}_{8}+12 \mathrm{HNO}_{3}
$$

$3 \mathrm{UO}_{2}\left(\mathrm{NO}_{3}\right)_{3}+2 \mathrm{NO}_{2}+\mathrm{NO}+6 \mathrm{H}_{2} \mathrm{O}$

Laju alir gas NOx $\left(0,0345 \mathrm{~m}^{3} / \mathrm{j}\right)$ dianggap sebagai aliran yang kecil, sehingga pemilihan jenis packing pun harus berukuran kecil. Jenis dan ukuran serta parameter packing yang tersedia menggunakan jenis pall ring, ralu ring, dan nor-pac ring sebagaimana ditunjukkan pada Gambar 2 dan Tabel 1. Selanjutnya dengan mensimulasi laju alir gas (dari 0,0345; 0,$0670 ; 0,1035$; dst) maka berdasar pada nor-pac ring), dilakukan dengan cara simulasi laju alir fluida (gas dan air) terhadap diameter, luas permukaan efektif packing, pressure drop, koefisien perpindahan massa, tinggi kolom packing, dan tinggi menara dengan cara memasukkan ke dalam persamaan-persamaan yang sesuai menggunakan program EXCEL. Dengan cara yang sama, berturut-turut disimulasikan penyerapan gas NOx, faktor flooding, tekanan operasi, dan temperatur terhadap ukuran (dimensi) menara absorber.

\section{HASIL DAN PEMBAHASAN}

Berdasarkan hasil perhitungan, proses pelarutan sebanyak $1500 \mathrm{~g}$ serbuk $\mathrm{U}_{3} \mathrm{O}_{8}$ dengan larutan asam nitrat $\left(\mathrm{HNO}_{3}\right)$ diperoleh laju alir gas NOx sebesar 0,0345 $\mathrm{m}^{3} / \mathrm{j}$. Proses pelarutan serbuk $\mathrm{U}_{3} \mathrm{O}_{8}$ dengan asan nitrat $\left(\mathrm{HNO}_{3}\right)$ berlangsung menurut persamaan reaksi: tahapan perhitungan menara absorber (pers. 1-50), maka diperoleh berturut-turut nilai diameter menara, luas permukaan efektif packing, pressure drop, koefisien perpindahan massa, tinggi kolom packing, dan tinggi menara absorber seperti ditunjukkan pada Gambar 3 hingga Gambar 7 sebagai fungsi jenis packing. Demikian juga simulasi dilakukan terhadap laju alir air (dipilih 360 ; 720 ; 1080 ; dst) 

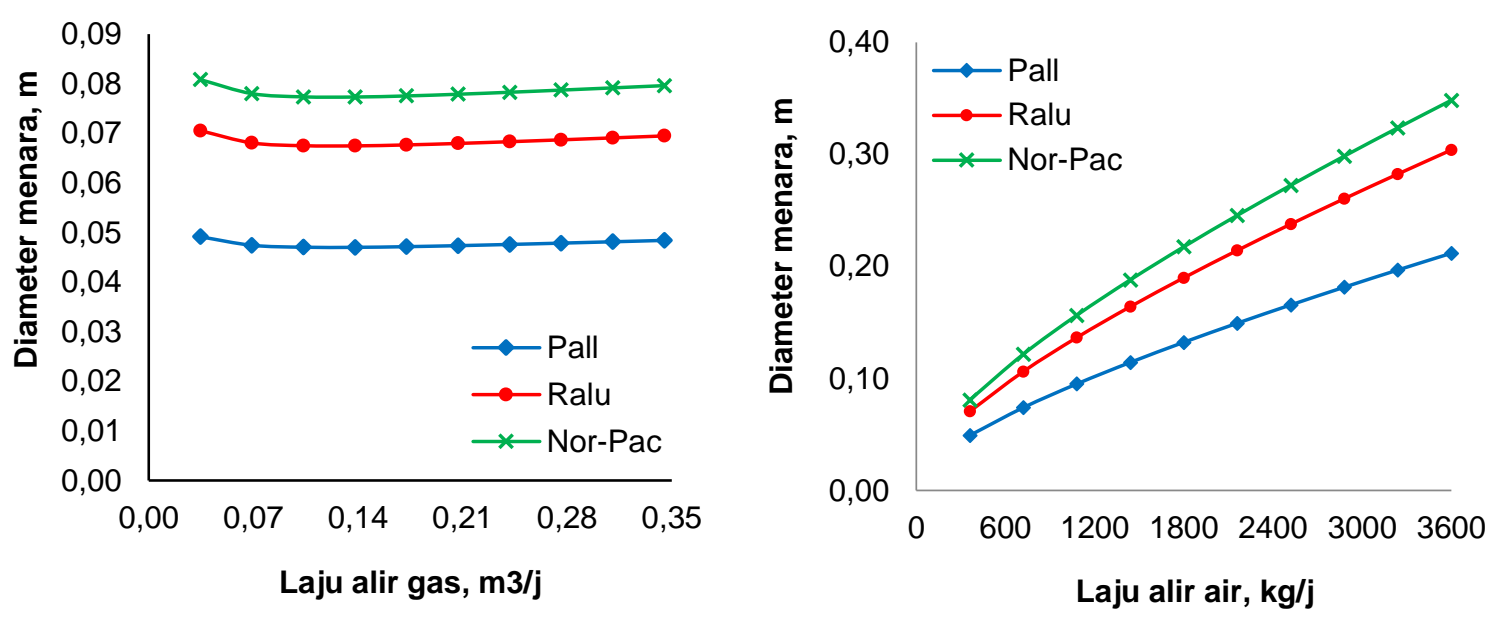

Gambar 3. Hasil perhitungan diameter menara terhadap laju alir fluida sebagai fungsi jenis packing
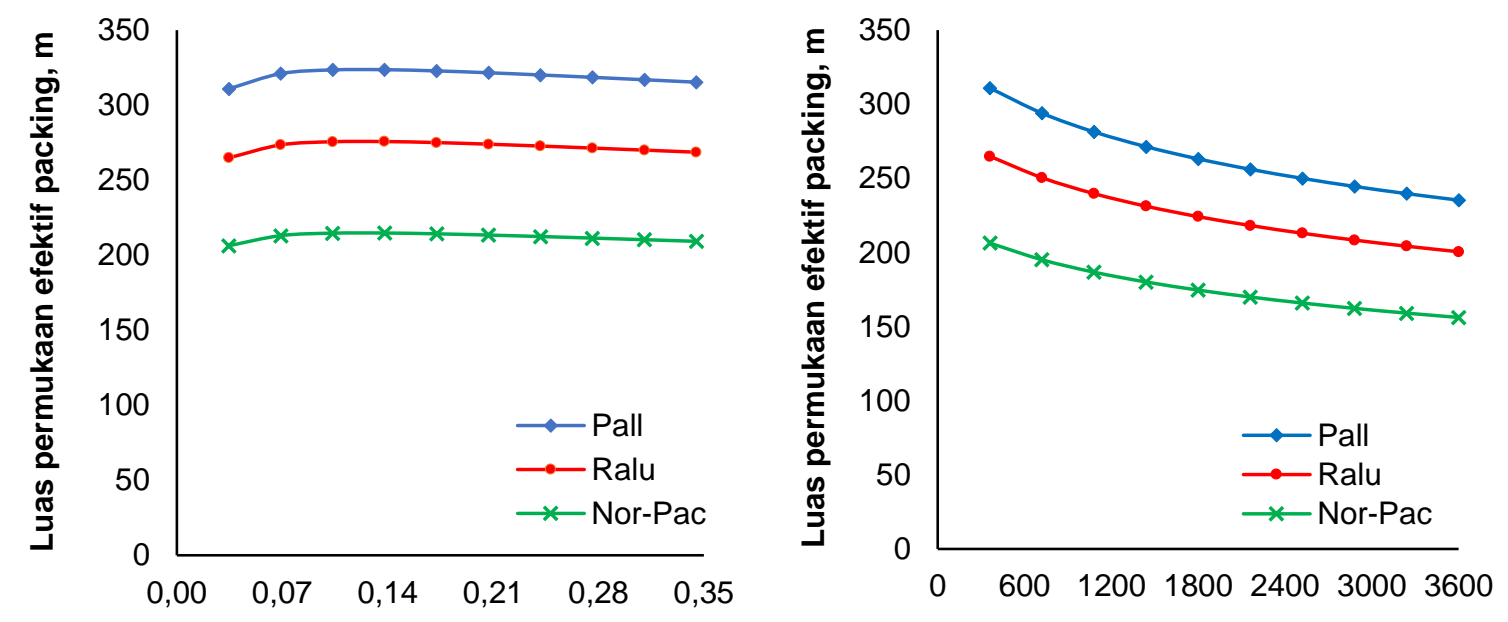

Laju alir gas, $\mathrm{m} 3 / \mathrm{j}$

\section{Laju alir air, kg/j}

Gambar 4. Hasil perhitungan luas permukaan efektif packing terhadap laju alir fluida sebagai fungsi jenis packing.
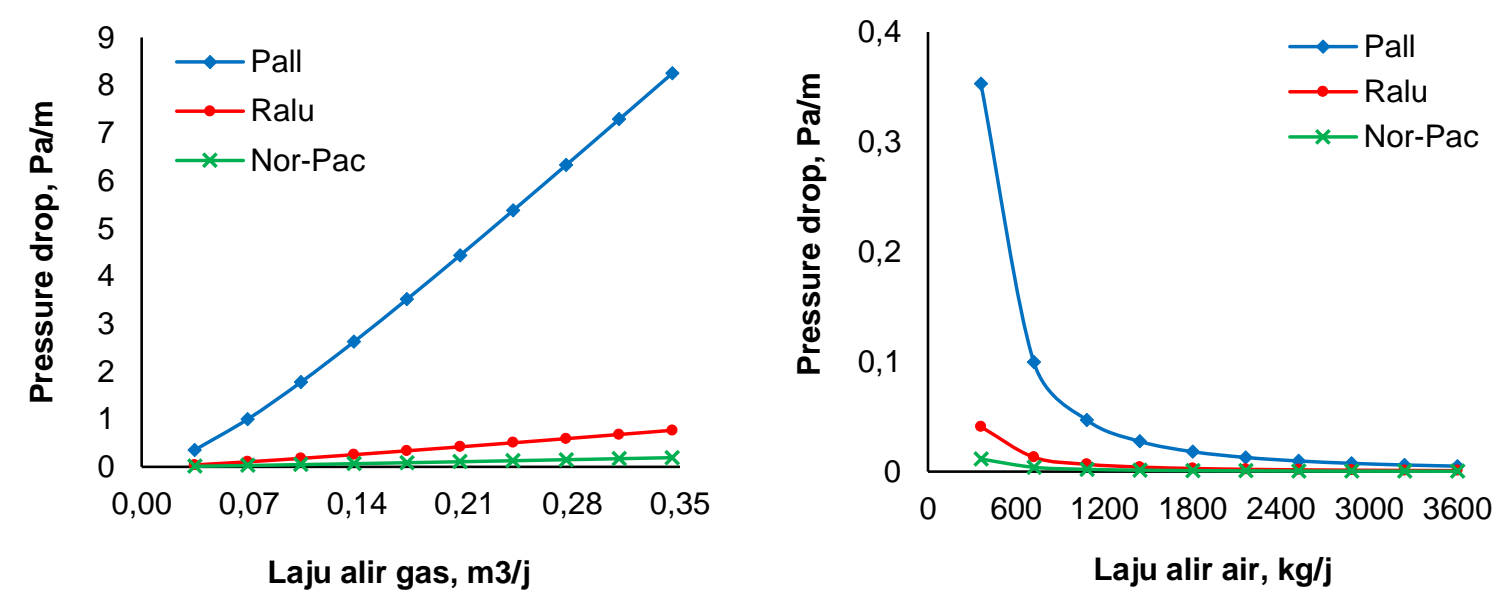

Gambar 5. Hasil perhitungan pressure drop terhadap laju alir fluida sebagai fungsi jenis packing. 

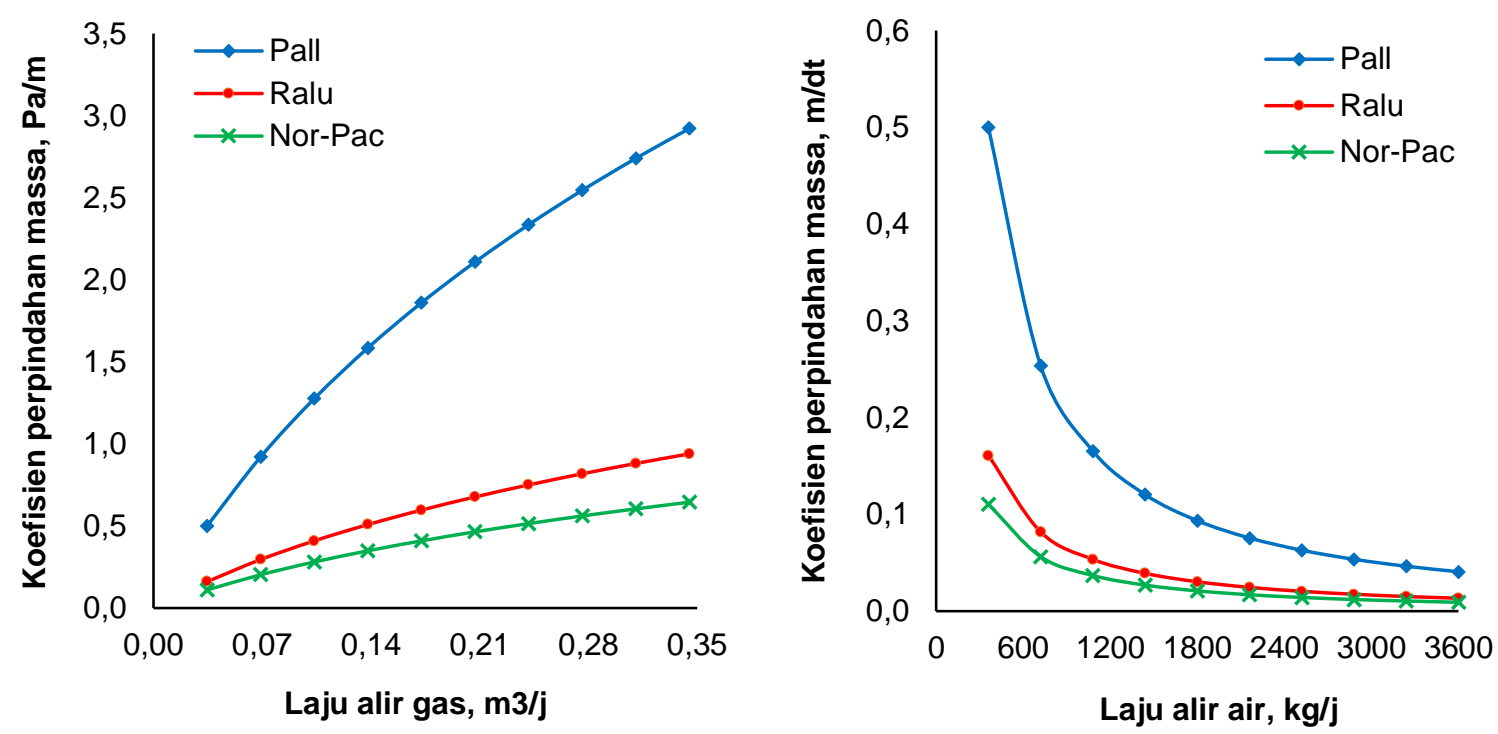

Gambar 6. Hasil perhitungan koefisien perpindahan massa terhadap laju alir fluida sebagai fungsi jenis packing.
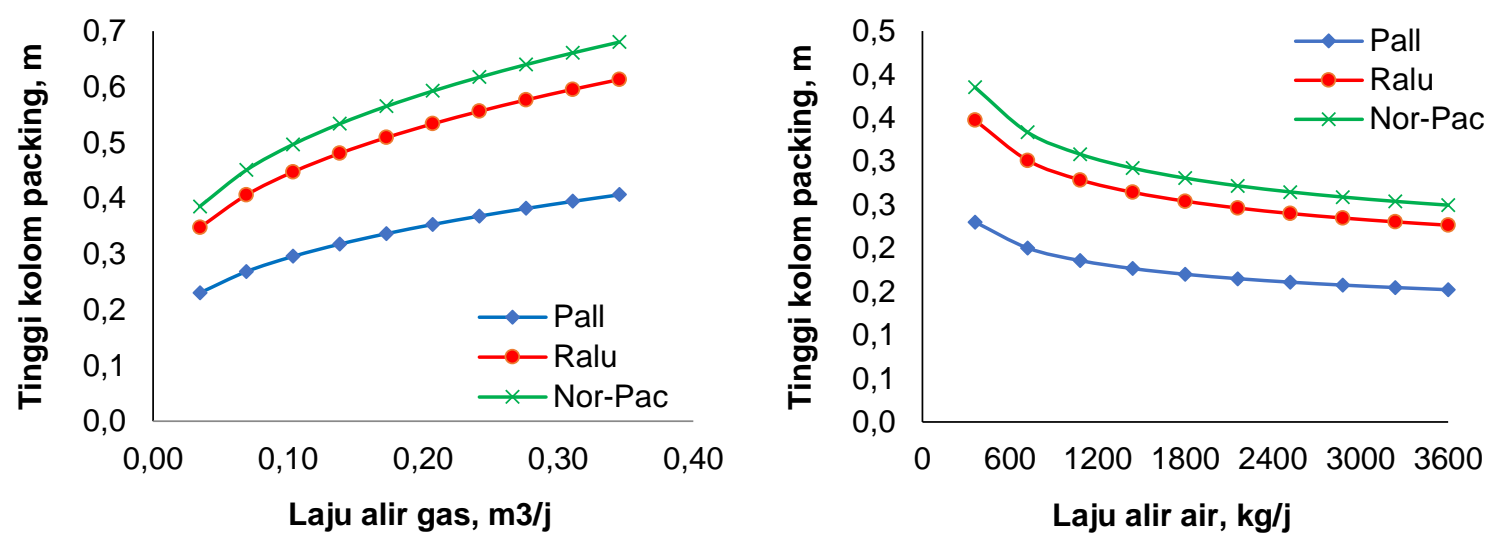

Gambar 7. Hasil perhitungan tinggi kolom packing terhadap laju alir fluida sebagai fungsi jenis packing

Pada Gambar 3, dengan simulasi laju alir gas, tampak bahwa pengaruh peningkatan laju alir gas tidak terlalu signifikan terhadap diameter menara, sedangkan penambahan laju alir air menghasilkan diameter menara bertambah besar. Menurut hasil simulasi perhitungan, hal ini disebabkan laju alir gas yang kecil $\left(0,0345 \mathrm{~m}^{3} / \mathrm{j}\right)$ dan laju alir air yang besar (360 $\mathrm{kg} / \mathrm{j})$. Disamping itu, faktor lain yang mempengaruhi hasil perhitungan adalah porositas packing, kecepatan fluida, dan kondisi flooding. Pada situasi ini, packing jenis pall-ring menjadi pilihan karena membutuhkan diameter yang lebih kecil dibanding packing jenis lainnya.

Hasil perhitungan pada Gambar 4. tampak bahwa nilai luas permukaan efektif packing terdapat kecenderungan menurun pada kondisi kenaikan laju alir fluida (gas dan air). Kinerja suatu packing dikatakan baik apabila seluruh permukaan packing dapat secara efektif memberikan luas kontak yang besar dengan fluida yang mengalirinya, sehingga luas kontak yang besar akan diperoleh pada laju alir fluida yang rendah. Pada laju alir fluida yang semakin besar, akan menyebabkan luas permukaan efektif 
packing semakin kecil, sehingga kemungkinan besar menghasilkan efisiensi pemisahan yang lebih rendah[14]. Tampak juga pada Gambar 4. bahwa packing jenis pall ring mempunyai luas kontak permukaan efektif paling besar dibanding dengan packing jenis lainnya.

Sementara itu faktor-faktor yang diperlukan dalam perhitungan pressure drop adalah diameter partikel, parameter hidrolika packing, kecepatan dan waktu tinggal fluida, serta gravitasi. Nilai pressure drop akan bertambah besar bila menara dan packing dialiri fluida dengan kecepatan yang rendah karena kecepatan aliran fluida yang rendah berpotensi menyebabkan gaya gesek dan resistensi (ketahanan) yang besar[15]. Pressure drop berkaitan erat dengan viskositas fluida. Viskositas tinggi akan menahan laju aliran air ke bawah menara semakin rendah, sehingga akan menyebabkan kecepatan flooding yang rendah. Pada situasi seperti ini tampak pada Gambar 5. bahwa air yang mempunyai viskositas lebih besar menghasilkan pressure drop yang semakin rendah, demikian sebaliknya, kecepatan gas yang mempunyai viskositas rendah akan menghasilkan pressure drop lebih besar. Pada packing jenis pall ring, menghasilkan pressure drop yang besar dibanding packing jenis lainnya. $\mathrm{Hal}$ ini karena packing jenis pall-ring mempunyai luas permukaan efektif dan waktu tinggal yang lebih lama dibanding dengan packing jenis lainnya.

Untuk penentuan koefisien perpindahan massa total pada menara absorber, dapat digunakan metode Billet and Schultes pada sistem biner untuk jenis packing dengan diameter menara antara 6 $\mathrm{cm}$ hingga 1,4 m. Nilai koefisien perpindahan massa total diperoleh dari nilai perpindahan massa konvektif fasa gas dan air. Koefisien perpindahan massa konvektif fasa gas dipengaruhi oleh koefisien difusi gas, kondisi operasi, bilangan Reynold, bilangan Schmidt, tumbukan, dan faktor perpindahan massa.
Sementara itu koefisien perpindahan massa konvektif fasa air dipengaruhi oleh koefisien difusi air, waktu tunda, dan kecepatan air. Pada Gambar 6. tampak bahwa kenaikan laju alir gas menyebabkan kenaikan nilai koefisien perpindahan massa totalnya, namun sebaliknya dengan laju alir airnya. Hal ini karena pada laju alir gas yang rendah akan memberikan waktu dan kesempatan terjadi proses perpindahan massa dan difusi yang besar.

Menara packed-bed absorber adalah menara yang berisi sekumpulan packing. Tinggi kolom packing ditentukan dari kecepatan molar gas terhadap koefisien perpindahan massa total dari fluida yang mengalirinya. Ketinggian kolom packing yang baik apabila luas permukaan efektif, pressure drop, dan perpindahan massa dari masingmasing packing dapat dipenuhi pada ketinggian packing yang serendahrendahnya. Pada Gambar 7. tampak bahwa pada kenaikan laju alir gas akan menghasilkan kenaikan tinggi kolom packing, namun pada kenaikan laju alir air terjadi kecenderungan penurunan tinggi kolom packing. Hal ini karena pada laju alir rendah (gas), perbandingan kecepatan molar dan perpindahan massa total yang membesar pada koefisien distribusi fluida tetap sehingga menyebabkan menara semakin tinggi. Demikian juga pada laju alir yang besar (air) terdapat perbandingan kecepatan molar dan perpindahan massa total yang mengecil pada koefisien distribusi yang tetap, akan menyebabkan penurunan tinggi menara. Dari Gambar 7. dapat dikatakan bahwa menara absorber berisi packing jenis pall-ring telah memenuhi kriteria tinggi kolom packing yang baik.

Penentuan tinggi menara umumnya sangat dipengaruhi oleh laju alir atau kecepatan molar fluida selama aliran fluida di dalam menara. Tampak pada Gambar 8. bahwa pada kenaikan laju alir gas akan menghasilkan kenaikan tinggi menara, namun pada kenaikan laju alir air terjadi 
kecenderungan penurunan tinggi menara. Hal ini karena pada laju alir rendah (gas), perbandingan kecepatan molar dan perpindahan massa total yang membesar pada faktor absorbsi tetap menyebabkan menara semakin tinggi. Demikian juga pada laju alir yang besar (air) terdapat

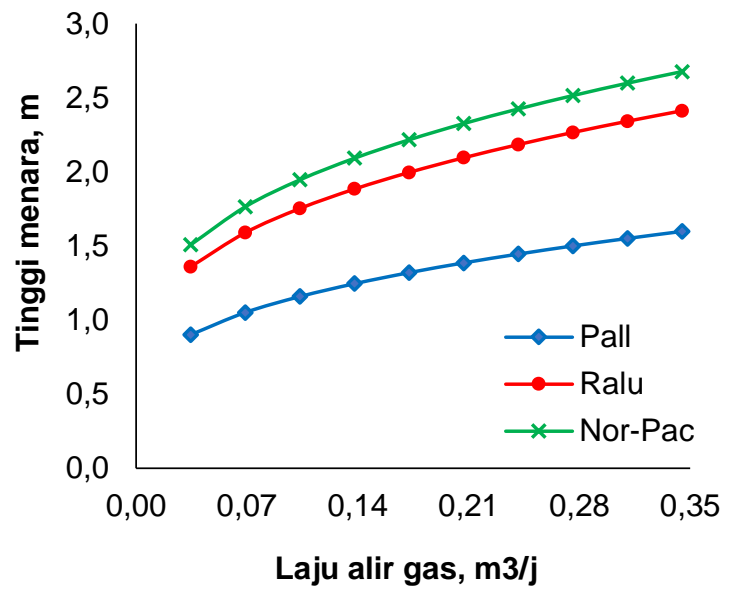

perbandingan kecepatan molar dan perpindahan massa total yang mengecil pada faktor absorbsi yang tetap, akan menyebabkan penurunan tinggi menara. Seperti halnya pada penentuan tinggi kolom packing, ketinggian menara yang baik dapat menggunakan packing jenis pall-ring.

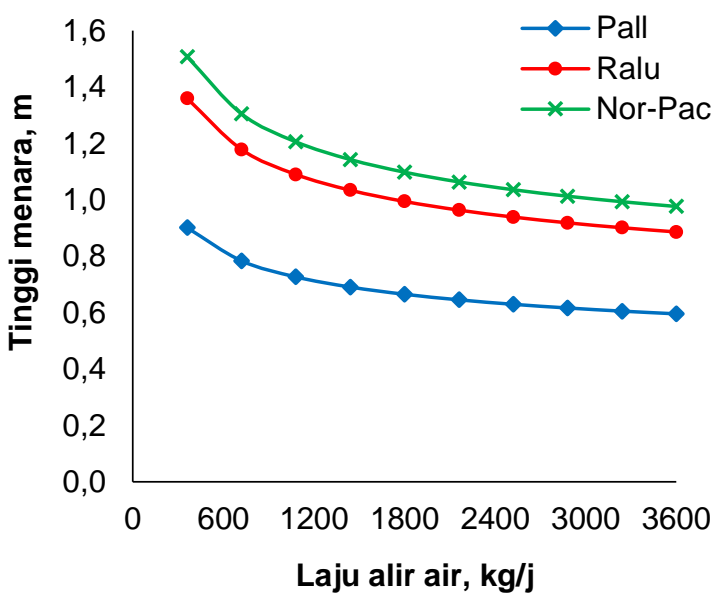

Gambar 8. Hasil perhitungan tinggi menara absorber terhadap laju alir fluida sebagai fungsi jenis packing.

Hasil simulasi perhitungan dan perancangan menara packed-bed absorber pada pengaruh jenis packing terhadap penyerapan gas NOx, faktor flooding, tekanan operasi, dan temperatur pada ukuran (dimensi) menara berturut-turut ditampilkan pada Gambar 9 dan Gambar 10.

Uranium dapat dimungkinkan terikut dalam gas NOx dianggap sebagai kontaminan atau aerosol meskipun dengan jumlah yang relatif sedikit, namun demikian mengingat sifat uranium yang radioaktif, menurut standar keselamatan udara buang, maka efisiensi penyerapan gas harus diatas $97 \%$. Hasil perhitungan yang ditampilkan dalam Gambar 9. tampak bahwa kenaikkan penyerapan gas NOx pada menara menyebabkan kenaikan tinggi menara (Z) dan tidak mempengaruhi diameter (D) dan tinggi kolom packing ( $H_{\text {toG }}$ ). Hal ini karena kenaikan jumlah gas NOx terserap akan membutuhkan waktu tinggal di dalam menara yang lama dan difusi gas terhadap luas permukaan efektif packing yang tinggi. Kenaikan faktor flooding tidak terlalu signifikan mempengaruhi penurunan dimensi menara dan tinggi kolom packing seperti ditunjukkan pada Gambar 9. Hal ini disebabkan oleh laju volumetrik air tetap meskipun kondisi flooding dinaikkan

Pengaruh kenaikkan tekanan operasi berdampak pada penurunan ukuran (dimensi) menara (tinggi kolom packing dan tinggi menara) seperti ditunjukkan pada Gambar 10. Tekanan operasi yang lebih tinggi dapat disebabkan oleh laju alir fluida yang tinggi. Laju alir fluida yang tinggi biasanya terdapat pada umpan yang mempunyai viskositas tinggi (air > gas). Sementara itu pengaruh kenaikkan temperatur tidak terlalu signifikan mempengaruhi penurunan tinggi menara dan tinggi kolom packing, serta tidak berpengaruh pada diameter menara. 

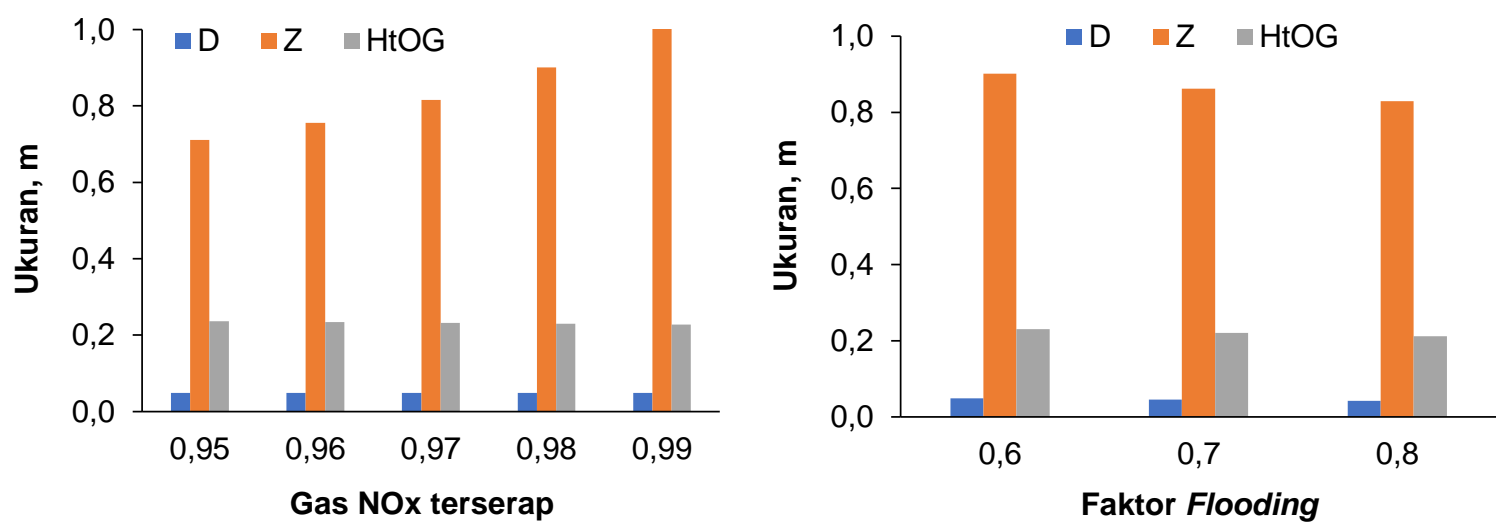

Gambar 9. Hasil perhitungan ukuran (dimensi) menara dari simulasi penyerapan gas NOx dan faktor flooding
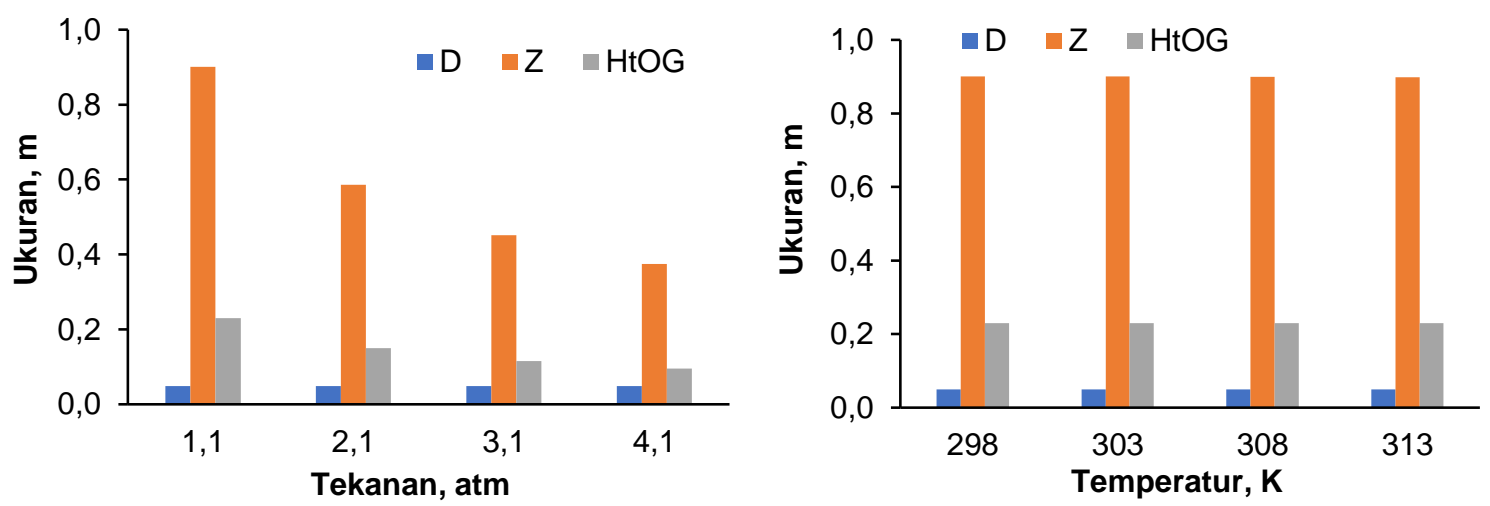

Gambar 10. Hasil perhitungan ukuran (dimensi) menara dari simulasi tekanan dan temperatur operasi.

\section{SIMPULAN}

Hasil perhitungan menunjukkan bahwa kenaikan laju alir gas tidak terlalu signifikan terhadap diameter menara, sedangkan kenaikan laju alir air menghasilkan diameter menara bertambah besar. Luas permukaan efektif packing cenderung menurun pada kenaikan laju alir fluida. Pressure drop, koefisien perpindahan massa, tinggi kolom packing, dan tinggi menara bertambah besar pada kenaikan laju alir gas, dan cenderung menurun bila laju alir air dinaikkan. Kenaikan penyerapan gas NOx menyebabkan kenaikan tinggi menara, sedangkan kenaikan faktor flooding menyebabkan penurunan tinggi kolom packing dan tinggi menara. Kenaikan tekanan dan temperatur operasi menyebabkan penurunan tinggi kolom packing dan tinggi menara. Packing jenis pall ring menjadi pilihan desain karena menghasilkan dimensi yang kecil/ekonomis dibanding jenis packing jenis ralu ring atau nor-pac ring.

\section{UCAPAN TERIMA KASIH}

Ucapan terimakasih ditujukan kepada bapak Ir. Agus Sumaryanto, M.S.M sebagai Kepala Pusat Teknologi Bahan Bakar Nuklir - BATAN dan ibu Ir. Ratih Langenati M.T sebagai Kepala Bidang Fabrikasi Bahan Bakar Nuklir - BATAN, yang keduanya telah mendorong untuk berpartisipasi pada program INSINAS-2019 sehingga dapat diterbitkan makalah ini sebagai bentuk tanggung jawab luaran laporan kegiatan. 


\section{DAFTAR PUSTAKA}

[1] W. Kristanti, B.S. Wahyudi, P. Indra, "Pengaruh diameter nozzle terhadap diameter gel pada proses gelasi eksternal kernel ceria stabilized zirconia," Jurnal IImiah Daur Bahan Bakar Nuklir Urania, vol. 25, no. 3, hal. 141-204, 2019.

[2] K.C. Jeong, Y.K. Kim, S.C. Oh, Y.W. Lee, "Preparation of an intermediate and particle characteristics for HTGR nuclear fuel," Journal of the Korean Ceramics Society, vol. 44, no. 2, pp. 124-131, 2007.

[3] R. Sukarsono, et. al, "Effect of sol concentration, aging and drying process on cerium stabilization zirconium gel produced by external gelation," Journal of Physics: Conference Series, 962 012056, 2018.

[4] Q. Ying, et. al, "The conceptual flowsheet of effluen treatment during preparing spherical fuel elements of HTR," Nuclear Engineering and Design, vol. 271, pp. 189-192, 2014.

[5] F. Zhang, Z.B. Zhang, "Absorption of nitrogen dioxide in water and dilute nitric acid solution with constant-volume absorption system," Chineese Journal of Inorganic Chemistry, vol. 29, no.1, pp. 95-102, 2013.

[6] A.P. Sanchez, E.J.P. Sanchez, R.S. Silva, "Design of packed bed absorption column considering four packing types and applying MATLAB," Nexo Revista Cientifica, vol. 29, no. 2, pp. 83-104, 2016.
[7] B. Raj Mohan and B.C. Meikap, "Control of $\mathrm{SO}_{2}$ from industrial effluents by a spray-cum bubble column scrubber, Science Alert, 2010, Available: https://scialert.net/fulltext/?doi=jas.2010 .3277.3282.

[8] A. Barghava, "Wet scrubbers-design of spray tower to control air pollutants," International Journal of Environmental Planning and Development, vol. 2, no. 1, 2016.

[9] G. Raja, "Cuboid Packed-Beds as Chemical Reactors?," Processes, vol. 6, no. 5, p. 44, 2018.

[10] H. Alsyouri, "Design of packed columns in chemical engineering unit operations," Engineering, 2015, Available: https://www.slideshare.net/alsyourih/de sign-of-packed-columns.

[11] K. Shah, "Types of packing material," ChemAlone: The Chemical Engineering eResources portal, 2016.

[12] E.E. Ludwig, "Applied process design for chemical and petrochemical plants," $3^{\text {rd }}$ ed, Oxford, U.K., ButterworthHeinemann, 1997.

[13] J. Benitez, "Principles and modern applications of mass transfer operations," $2^{\text {nd }}$ ed, Hoboken, U.S.A, John Wiley and Sons, 2009.

[14] X. Chen, et. al, "The uranium recovery from $\mathrm{UO}_{2}$ kernel production effluent," Nuclear Engineering and Design, vol. 310 pp. 187-191, 2016.

[15] U.L. Minne, A.J. Burger, C.E. Schwarz, "The effect of fluid properties and packing size on the hydrodynamics of packed columns," Chemical Engineering Transactions, vol. 69, pp. 31-36, 2018. 